\title{
Nutrient Content and In-vitro Starch Hydrolysis of Some Varieties of NERICA Rice
}

\author{
Otemuyiwa Israel Olusegun \\ Department of Chemistry, Obafemi Awolowo University, Ile-Ife, Nigeria \\ Tel: 234-805-478-6341_E-mail: otemuyisegun@oauife.edu.ng
}

Farotimi Oluwatosin Grace

Department of Chemistry, Obafemi Awolowo University, Ile-Ife, Nigeria

Falade Olumuyiwa Sunday

Department of Chemistry, Obafemi Awolowo University, Ile-Ife, Nigeria

Sanusi Kayode

Department of Chemistry, Obafemi Awolowo University, Ile-Ife, Nigeria

Adewusi Steve Adeniyi

Department of Chemistry, Obafemi Awolowo University, Ile-Ife, Nigeria

Received: December 30, 2017 Accepted: February 28, 2018 Published: March 2, 2018

doi:10.5296/jfs.v7i1.12385

URL: https://doi.org/10.5296/jfs.v7i1.12385

\begin{abstract}
This study investigated the nutrient quality and the glycemic index of some varieties of Africa (NERICA) rice. The nutrients were analyzed using the official methods of analysis (AOAC), minerals using Atomic Absorption Spectrophotometer (AAS) after wet digestion, vitamins using a High performance Liquid Chromatography (HPLC), while in-vitro starch hydrolysis was performed using multi-enzyme digestion method. The results were compared with that of
\end{abstract}




\section{Macrothink}

Aroso (imported rice). The content of moisture, ash, fiber, fat, protein and carbohydrate ranged from 8.2 to $9.8,0.02$ to $0.09,0.3$ to $0.5,2.4$ to $5.7,5.9$ to 13.0 , and 74.4 to $82.8 \%$, respectively. Iron varied from 30 to $69.3 \mathrm{mg} / \mathrm{kg}$, zinc, (2.4 to 10.4) copper, (0.5 to 4.6) calcium (43.4 to 146) and magnesium from 85.5 to $368 \mathrm{mg} / \mathrm{kg}$. Ascorbic acid ranged from (8.1 to $36.2 \mathrm{mg} / \mathrm{kg}$, pyridoxine (372 to $789 \mathrm{mg} / \mathrm{kg}$ ), thiamine (116 to $383 \mathrm{mg} / \mathrm{kg}$ ) and folate from 66.6 to $142 \mathrm{mg} / \mathrm{kg}$. Reducing sugar, total sugar and starch (mg / g) ranged from 60 to 117 and 96 to 157, and 171 to $188 \mathrm{mg} / \mathrm{g}$, respectively, while amylose ranged between 19 and $30 \%$. There were negative correlation between glycemic index and fibre $(r=-0.814)$; and between hydrolysis index and fibre $(\mathrm{r}=-0.731)$. The study showed that NERICA rice contain essential nutrients but it has high glycemic index could be a risk factor for disease like Diabetes mellitus

Keywords: Amylose, NERICA rice, Glycemic index, Diabetes mellitus

\section{Introduction}

Rice is an important staple food crop for millions of households and it is also rapidly becoming a staple in Sub Saharan Africa (Futakuchi, 2009). Rice production in Africa is faced with enormous challenges such as low yield and inferior quality compared to foreign rice. As a result, most of the rice consumed in Africa was imported from technologically advanced nations, about $32 \%$ of global rice produced in 2006 was imported into Africa and the rate of importation is growing astronomically every year. Africa's emergence as a big rice importer is explained by the fact that during the last decade rice has become the most rapidly growing food source in sub-Saharan Africa (Africa Rice Center, 2008). The preference for rice as against other plant foods like cassava, sorghum, yam and so on, is increasing most especially in urban areas. The increase in the rice consumption has been attributed to rising urbanization patterns, population and income growth, as well as changes in family occupational structures (Cadoni \& Angelucci, 2013).

Production of Africa rice dubbed NERICA by Africa Rice Centre was described as major breakthrough in the rice production. The new rice varieties were produced by cross breeding African rice (Oryza glabberima Steud.) with Asian rice (Oryza sativa L.). The new rice combined the best trait of both parents. These traits include high yield varieties from Asian parent and the ability from African parent to thrive in hazard environments. NERICA varieties have been observed to have unique qualities like shorter duration, high yields, tolerance to major stress, higher protein and good taste compare to the traditional rice varieties (Jones et al., 1997; DingKuhn et al., 1998; Auderbert et al., 1998).

Rice is a high carbohydrate food with about $85 \%$ of the energy from carbohydrate, $7 \%$ from fat, and $8 \%$ from protein (Oelke, 1976). It is easily digested producing high glycemic index (GI) (Wolever \& Mchling, 2002). There is a controversy on the effect of the consumption of rice on the risk of Diabetes mellitus while some studies believed that rice consumption could increase blood glucose level, others did not (Rohman et al., 2014). Regular consumption of foods with high glycemic index (GI), particularly refined or processed carbohydrate, is associated with the development of certain chronic diseases, such as obesity, Type 2- diabetes, increased risk of cardiovascular diseases and certain forms of cancer (Zabidi, \& Abdul - Aziz, 2009). 


\section{Macrothink}

Variations in composition and cooking quality of rice depend mainly on the genetic and environmental factors, physicochemical characteristics, amylose content as well as gelatinization temperature (Thomas et al., 2013). Increasing rice production and improving its nutritional value is expected to make a tremendous contribution to improving the livelihoods of millions of households.

New rice for Africa (NERICA) has become a potential area for scientific research. The major focus of research on NERICA has been on the agronomical development of different cultivars through hybridization and genetic modifications (Virmani, 2002). Recently some research efforts have been conducted on the proximate and amino acid composition of some lines of NERICA rice (Anuonye et al., 2016), functional and physicochemical properties of NERICA starches and flours (Falade et al, 2014) and the effect of parboling on the proximate and mineral composition of NERICA 14 cultivars (Ayamdoo et al., 2015). There is dearth of information on the starch digestibility and glycemic index of some varieties of NERICA rice hence, the need for present study. The objectives of this study were to evaluate the nutrient content and in-vitro starch hydrolysis of some varieties of NERICA rice in order to predict their nutritional value and glycemic index.

\section{Materials and Methods}

\subsection{Chemicals and Reagents Used}

Pyridoxine, Niacinamide, Folic acid, Ascorbic acid and Thiamine were purchased from Sigma (Sigma-Aldrich, Germany), HPLC grade methanol (Sigma), Sodium-monohydrogen phosphate (BDH), Pepsin, $\alpha$ - Amylase, Amyloglucosidase, Potassium Ferricyanide and 2,4-dinitrosalicylic acid were from Sigma (Sigma-Aldrich, Germany); Other reagents are of analytical grade.

\subsection{Sample and Sample Preparation}

The samples of NERICA rice were collected from Africa Rice Centre, International Institute of Tropical Agriculture (IITA), Ibadan, Nigeria. They are NERICA 2, NERICA 5, NERICA 6, NERICA 7, NERICA 8 and NERICA 9. The husks and the bran were manually removed without parboiling; the rice kernels were washed clean with distilled water, and dried at $50^{\circ} \mathrm{C}$ in the oven (Gallenkamp Oven Model SA 9059 B).

A portion of the above samples were processed into powder, sieved with No 72 mesh size, (Griffin and George Ltd., London) stored in plastic containers with screw cap. The samples were kept in the freezer until used.

\subsection{Chemical Analysis}

\subsubsection{Proximate Composition}

The samples were analyzed for proximate composition using the official method of AOAC (AOAC, 2000): moisture content (AOAC method 925.45A), ash (AOAC method 941.12), total lipid (AOAC method 950.54), fiber (AOAC method 973.18), crude protein ( $\mathrm{N}$ 5.70) (AOAC method 920.165) and carbohydrate by difference.

Energy value was estimated by Atwater principle (James, 1996) using the expression;

$$
\text { Energy }(\mathrm{kJ} / \mathrm{g})=(\text { carbohydrate } \mathrm{x} 17)+(\text { protein } \mathrm{x} 17)+(\text { fat } \mathrm{x} 37)
$$




\section{Macrothink}

\subsubsection{Minerals}

Minerals determination was carried out on samples digested with the mixture of nitric acid and perchloric acid mixture $\left(\mathrm{HNO}_{3} / \mathrm{HClO}_{4} ; 4: 1, \mathrm{v} / \mathrm{v}\right)$ and the mineral content of the digestate analyzed using the Atomic Absorption Spectrophotometer (Alpha 4 Model, Fisons Chem-Tech Analytical, UK)

\subsubsection{Vitamins}

Quantitative analysis of water soluble vitamins was done simultaneously using a High Performance Liquid Chromatography according to the method of Khor and Tee (1996) as modified by Otemuyiwa and Adewusi (2013).

The HPLC used was a reversed phase type. The chromatographic separation column consisted of a stainless steel $(4.6 \times 150 \mathrm{~mm})$ Eclipse XDD, and $5 \mu \mathrm{m}$ mbondapack C18 column. The HPLC was equipped with an integrated UV detector which was set at $254 \mathrm{~nm}$ wavelength to monitor the column effluent. The mobile phase comprised of $90 \%$ of $0.01 \mathrm{M}$ sodium mono-hydrogen phosphate and $10 \%$ HPLC grade methanol. The mobile phase was sonicated for 30 min before use. The elution was isocratic and the flow rate was $0.60 \mathrm{~mL} /$ $\min$.

\subsection{Preparation of Standard and Sample Extraction}

The stock standard solutions of thiamine, pyridoxine and niacin were prepared by dissolving $20 \mathrm{mg}$ of each standard in $0.1 \mathrm{M}$ hydrochloric acid in $10 \mathrm{ml}$ standard flask and made up to mark with the acid. Also, of Folic acid and ascorbic acid (20 mg each) were prepared with 0.1 $\mathrm{M}$ sodium hydroxide in $10 \mathrm{ml}$ standard flask and made up to mark with the solution. The working standards were prepared from the stock standard solutions by taking $0.1,0.2,0.3,04$, $0.5 \mathrm{mg} / \mathrm{ml}$ of the stock into $10 \mathrm{~mL}$ standard flask and made up to mark with either $0.1 . \mathrm{M} \mathrm{HCl}$ or $\mathrm{NaOH}$.

The samples $(2.0 \mathrm{~g})$ each were extracted with $20 \mathrm{ml}$ of $0.1 \mathrm{M}$ Hydrochloric acid in $100 \mathrm{~mL}$ Erlenmeyer flask, another portion of the samples $(2.0 \mathrm{~g})$ was extracted with $0.1 \mathrm{M}$ sodium hydroxide. The beakers were placed in a water bath at $40^{\circ} \mathrm{C}$ for $5 \mathrm{~min}$. The solution was placed in a $25 \mathrm{ml}$ standard flask and made up to volume with the solvent. Both the standard and the samples were sonicated and injected into HPLC. Analysis was done in triplicate. Vitamins were identified from their retention times and the concentrations were calculated using linear equation obtained from the calibration curve of the standards. The linear equation is as shown below

$\begin{array}{lc}\text { Ascorbic acid } & \mathrm{y}=92511.36027 \mathrm{x}+1048.70238 \\ \text { Pyridoxine } & \mathrm{y}=18536.68580 \mathrm{x}+16.31764 \\ \text { Thiamine } & \mathrm{y}=14213.42610 \mathrm{x}+(-284.46318) \\ \text { Folic Acid } & \mathrm{y}=25719.56704 \mathrm{x}+(-327.04686) \\ \text { Niacin } & \mathrm{y}=44725.448 \mathrm{x}+(-586.167)\end{array}$

\subsection{Determination of Total and Reducing Sugar content}

Soluble sugar was extracted from $2.0 \mathrm{~g}$ sample with $85 \%$ ethanol using soxhlet extractor and refluxed for $2 \mathrm{~h}$ as described by Bainbridge et al. (1996). Reducing sugar and total sugar were 


\section{MInstitute ${ }^{\text {Macrothink }}$}

determined from the ethanolic extract by the ferricyanide method (AOAC, 1984). Glucose was used as a standard and the glucose content of the sample was calculated using a linear equation

$$
\mathrm{y}=1.6216-0.001 \mathrm{x} \quad\left(\mathrm{R}^{2}=0.972\right)
$$

\subsection{Determination of Total Starch Content}

The Total starch content of the samples was determined on the residue obtained after ethanolic extraction of sugar. Residue $(200 \mathrm{mg}$ ) was refluxed with $0.7 \mathrm{M} \mathrm{HCl}$ for $2.5 \mathrm{~h}$ Bainbridge et al. (1996). The acid hydrolysate was neutralized to $\mathrm{pH} 7.0$ using $5.0 \mathrm{M} \mathrm{NaOH}$, pour into $500 \mathrm{~mL}$ standard flask and made up to volume with distilled water. The hydrolysate was filtered through a Whatman no. 541 filter paper and the starch was determined as the reducing sugar using the ferricyanide method (AOAC, 1984). The glucose content was calculated as shown for reducing sugar and then converted to starch by multiplying with 0.9 .

\subsection{Determination of Amylose Content}

Amylose content in rice samples were determined based on the Iodine-binding procedure as described by Thomas et al, (2013). The sample (100 mg) was measured into $100 \mathrm{~mL}$ standard flask, $1.0 \mathrm{ml}$ of $95 \%$ ethanol and $9.0 \mathrm{ml}$ of $1.0 \mathrm{M} \mathrm{NaOH}$ were added, the mixture was heated on a boiling water bath for 10 min to gelatinize the starch. The gelatinized starch solution (5.0 ml) was transferred to a $100 \mathrm{ml}$ standard flask, $1.0 \mathrm{~mL}$ of $1.0 \mathrm{M}$ acetic acid and $2.0 \mathrm{ml}$ of freshly prepared Iodine reagent were added and made up to volume with distilled water. Iodine reagent was prepared by dissolving $0.2 \mathrm{~g}$ of iodine and $2.0 \mathrm{~g}$ potassium iodide with distilled water in a $100 \mathrm{ml}$ volumetric flask. The contents were thoroughly vortex mixed and allowed to stand for $20 \mathrm{~min}$. The absorbance was measured at $620 \mathrm{~nm}$ using a UV-Spectrophotometer (Model AA-6650, Shimadzu Co. Japan). The amylose content was calculated from the linear equation $\left(y=0.806+9.661 \mathrm{R}^{2}=0.899\right)$ obtained from the standard curve of potato amylose

\subsection{In-vitro Starch Hydrolysis}

The in-vitro starch digestibility of the bread samples was determined by multi-enzyme digestion method as described by Falade et al. (2005). Each sample (250 mg) was digested with $20 \mathrm{mg}$ pepsin (Sigma; CAS 2001/75-6, code 10132561), (prepared by adding1.0 g of pepsin $/ 10 \mathrm{~mL}$ of $\mathrm{HCl}-\mathrm{KCl}$ buffer) for $1 \mathrm{~h}$ in a shaking water bath at $37^{\circ} \mathrm{C}$. The $\mathrm{pH}$ of the digestate was adjusted to 6.9 using Tris - maleate buffer (pH 6.9). Then $5.0 \mathrm{~mL}$ of (2.6 IU in 5 $\mathrm{ml}$ buffer $\mathrm{pH}$ 6.9) was added to the digestate which was incubated at $37^{\circ} \mathrm{C}$ in a shaking water bath. One $\mathrm{ml}$ of sample aliquots was collected at intervals of $30 \mathrm{~min}$ for $180 \mathrm{~min}$. To these aliquots, $3 \mathrm{ml}$ of $0.4 \mathrm{M}$ sodium acetate buffer ( $\mathrm{pH} 4.75$ ) and $60 \mu 1$ amyloglucosidase (Sigma, No; 10105-5GF,70 ui/mg. Aspegilius niger) were added and incubated at $60{ }^{\circ} \mathrm{C}$ for $5 \mathrm{~min}$ to hydrolyse the starch to glucose. The glucose released was determined using 3,5dinitrosalicylic acid (Miller, 1959). The concentration of glucose was calculated from the linear equation of glucose standard $\left(\mathrm{R}^{2}=0.980\right)$ and glucose was converted into starch by multiplying with 0.9 .

The rate of starch digestion was expressed as percentage total starch hydrolysed at different times. The hydrolysis index was calculated as relation between the AUC for the food and the AUC for the reference food (white bread) expressed as percentage. The glycemic index (GI) 
was estimated using the equation of Goni et al. (1997).

\subsection{Statistical Analyses}

Results were expressed as mean and standard deviation of triplicate analysis and the means of the data were separated using one-way analysis of variance (ANOVA), Duncan Multiple test was used to test the levels of significant difference $(\mathrm{p} \leq 0.05)$. Pearson correlation was used to determine correlation between amylose content, and glycemic index, and also between amylose and hydrolysis index. Microsoft Excel package and GraphPad InStat version 3.06 for Windows 2003 software's were used for the statistical analyses

\section{Results and Discussion}

\subsection{Proximate Composition}

The proximate composition of NERICA rice samples were presented in Table 1. The moisture content ranged from 8.2 to $9.8 \%$, for NERICA-2 and NERICA-7, respectively The highest moisture content was reported for NERICA-7, The range of moisture content obtained in this study compared with 9.4 to $10.0 \%$ reported earlier for NERICA rice (Anuonye et al., 2016), but lower than 13.0 to $13.47 \%$ reported for TGS - 3, and TGS - 25 rice (Falade et al., 2014). Low moisture content indicated a better stability of the paddy rice against breakage during milling, and a better shelf life (Anuonye et al., 2016). The moisture content of all these samples was lower than $13 \%$ and $12 \%$ recommended for short term storage (6months) and long term storage, respectively (Thomas et al., 2013). The moisture content of plant foods has been reported to be affected by maturity, freshness and agronomic practice during cultivation (Olajiire \& Azeez, 2011). The moisture content is also believed to affect the palatability of cooked rice (Oko \& Ugwu, 2011).

The ash ranged from 0.05 to $0.4 \%$, for NERICA-5 and NERICA-7, respectively. The ash content is an indirect way of estimating the mineral content of sample. The ash content of these samples was lower than $1.6-2.3 \%$ and $2.2 \%$ reported for NERICA-14 and Jasmine rice, respectively (Ayamdoo et al., 2015).

The fat content varied between 2.4 to $5.7 \%$ for Aroso and NERICA - 6, respectively. The value recorded in this work was higher than the range of 0.5 to $3.5 \%$ reported for milled local Nigerian rice (Oko et al., 2012) but lower than the range of 5.0 to $6.9 \%$ reported for NERICA rice (Anuonye et al., 2016).

Protein was between 5.9 to $13.0 \%$, NERICA -8 recorded the highest value. These values were within the range of 7.3 to $7.4 \%$ found in some varieties of rice (Ayamdoo et al., 2015). The protein content reported for Aroso (5.9\%) was lower than in NERICA, this is expected because Aroso had been subjected to processing like parboiling, milling and polishing which have been reported to reduce the protein content of rice (Anuonye et al., 2016). High protein content of NERICA rice is of great nutritional advantage especially in Nigeria where rice is the major staple. Its consumption will no doubt reduce malnutrition due to protein deficiency. The most abundant macronutrient in rice is carbohydrate. It ranges from 74.4 to $82.8 \%$. Carbohydrate is reported to account for high energy content of rice hence NERICA rice could be a good source of energy.

\subsection{Minerals}

The results of mineral content are presented in Table 1 . The results showed that iron, zinc and 


\section{Mll Macrothink}

copper ranged from 30.0 to $69.3 \mathrm{mg} / \mathrm{kg}, 2.4$ to $10.4 \mathrm{mg} / \mathrm{kg}$, and 0.5 to $4.6 \mathrm{mg} / \mathrm{kg}$, respectively. Also calcium and magnesium varied from 43.4 to $146 \mathrm{mg} / \mathrm{kg}$ and 85.5 to 358 $\mathrm{mg} / \mathrm{kg}$, respectively. Aroso recorded least value for almost all the minerals investigated. This implies that NERICA rice is more nutritious than Aroso, thus consumption of NERICA rice in Africa could help reduce mineral deficiency diseases such as anaemia.

Table 1. Proximate composition, mineral and vitamin content of Nerica rice varieties

\begin{tabular}{llllllll}
\hline Parameters & NERICA 2 & NERICA 5 & NERICA 6 & NERICA 7 & NERICA 8 & NERICA 9 & Aroso \\
\hline Moisture (\%) & $8.2 \pm 0.7^{\mathrm{b}}$ & $9.1 \pm 0.4^{\mathrm{a}}$ & $8.5 \pm 0.5^{\mathrm{a}}$ & $9.8 \pm 0.5^{\mathrm{a}}$ & $9.3 \pm 0.3^{\mathrm{a}}$ & $9.5 \pm 0.3^{\mathrm{a}}$ & $8.2 . \pm 0.1^{\mathrm{b}}$ \\
Ash Content (\%) & $0.06 \pm 0.02^{\mathrm{d}}$ & $0.05 \pm 0.01^{\mathrm{d}}$ & $0.09 \pm 0.02^{\mathrm{cd}}$ & $0.4 \pm 0.01^{\mathrm{b}}$ & $0.2 \pm 0.1^{\mathrm{c}}$ & $0.4 \pm .05^{\mathrm{bc}}$ & $0.4 \pm 0.07^{\mathrm{cd}}$ \\
Fiber (\%) & $0.5 \pm 0.03^{\mathrm{a}}$ & $0.3 \pm 0.01^{\mathrm{b}}$ & $0.4 \pm 0.07^{\mathrm{b}}$ & $0.3 \pm 0.02^{\mathrm{b}}$ & $0.3 \pm 0.02^{\mathrm{b}}$ & $0.4 \pm .06^{\mathrm{ab}}$ & $0.3 \pm 0.01^{\mathrm{c}}$ \\
Fat (\%) & $3.4 \pm 0.14^{\mathrm{c}}$ & $4.5 \pm 0.02^{\mathrm{b}}$ & $5.7 \pm 0.05^{\mathrm{a}}$ & $2.6 \pm 0.04^{\mathrm{e}}$ & $2.8 \pm 0.02^{\mathrm{d}}$ & $3.5 \pm .05^{\mathrm{c}}$ & $2.4 \pm 0.1^{\mathrm{d}}$ \\
Protein (\%) & $11.6 \pm 0.01^{\mathrm{b}}$ & $10.1 \pm 0.01^{\mathrm{d}}$ & $7.9 \pm 0.02^{\mathrm{e}}$ & $10.8 \pm 0.01^{\mathrm{c}}$ & $13.0 \pm 0.01^{\mathrm{a}}$ & $7.9 \pm 0.02^{\mathrm{e}}$ & $5.9 \pm 0.2^{\mathrm{d}}$ \\
Carbohydrate (\%) & $76.7 \pm 0.9^{\mathrm{b}}$ & $76.2 \pm 0.5^{\mathrm{d}}$ & $77.8 \pm 0.6^{\mathrm{c}}$ & $75.8 \pm 0.7^{\mathrm{e}}$ & $74.4 \pm 0.5^{\mathrm{f}}$ & $78.3 \pm 0.5^{\mathrm{a}}$ & $82.8 \pm 0.3^{\mathrm{b}}$ \\
Energy (kJ) & $1621 \pm 12^{\mathrm{ab}}$ & $1636 \pm 20^{\mathrm{a}}$ & $1630 \pm 16^{\mathrm{a}}$ & $1571 \pm 11 \mathrm{~b}^{\mathrm{c}}$ & $1588 \pm 0.9^{\mathrm{b}}$ & $1596 \pm 2.8^{\mathrm{b}}$ & $1596 \pm 1.8^{\mathrm{b}}$ \\
\hline Mineral mg / kg & & & & & & & \\
\hline Iron & $34.8 \pm 1.0^{\mathrm{bc}}$ & $69.3 \pm 0.7^{\mathrm{a}}$ & $32.4 \pm 4.5^{\mathrm{c}}$ & $34.8 \pm 2.1^{\mathrm{bc}}$ & $39.5 \pm 0.6^{\mathrm{b}}$ & $36.9 \pm 2.7^{\mathrm{b}}$ & $30 \pm 0.07^{\mathrm{d}}$ \\
Zinc & $6.6 \pm 0.8^{\mathrm{b}}$ & $10.4 \pm 1.6^{\mathrm{a}}$ & $6.8 \pm 2.4^{\mathrm{b}}$ & $5.4 \pm 0.15^{\mathrm{b}}$ & $7.1 \pm 0.1^{\mathrm{b}}$ & $6.9 \pm 2.0^{\mathrm{b}}$ & $2.4 \pm 0.8^{\mathrm{c}}$ \\
Copper & $4.6 \pm 0.2^{\mathrm{a}}$ & $3.7 \pm 0.3^{\mathrm{b}}$ & $4.6 \pm 0.3^{\mathrm{a}}$ & $4.2 \pm 0.0^{\mathrm{a}}$ & $4.3 \pm 0.1^{\mathrm{a}}$ & $2.9 \pm 1.5^{\mathrm{c}}$ & $0.5 \pm 0.1^{\mathrm{b}}$ \\
Calcium & $104 \pm 7.0^{\mathrm{c}}$ & $102 \pm 6.4^{\mathrm{c}}$ & $61.5 \pm 3.4^{\mathrm{d}}$ & $146 \pm 1.4^{\mathrm{a}}$ & $146 \pm 3.0^{\mathrm{a}}$ & $113 \pm 3.5^{\mathrm{b}}$ & $43.4 \pm 2.6^{\mathrm{b}}$ \\
Magnesium & $292 \pm 17^{\mathrm{b}}$ & $368 \pm 7.1^{\mathrm{a}}$ & $283 \pm 3.1^{\mathrm{b}}$ & $153 \pm 1.7^{\mathrm{c}}$ & $216 \pm 7.0^{\mathrm{e}}$ & $221 \pm 3.3^{\mathrm{de}}$ & $85.5 \pm 0.5^{\mathrm{e}}$ \\
\hline
\end{tabular}

*Aroso reference rice.

Mean $\pm \mathrm{SD}-$ Mean and standard deviation of replicate analysis.

Values with different superscript in the same row are significantly different $(\mathrm{P} \leq 0.001)$.

\subsection{Vitamins}

The chromatogram for vitamin standard was presented in Figure 1, and the results of water soluble vitamins were reported in Table 1. The content of ascorbic acid ranged from 8.1 to $36.2 \mathrm{mg} / \mathrm{kg}$, or NERICA-7 and NERICA-2, respectively. The value of ascorbic acid reported in this work was higher than 2 to $11 \mathrm{mg} / \mathrm{kg}$ reported for cooked foods obtained from Eatery (Otemuyiwa \& Adewusi, 2013). Ascorbic acid plays an important role in the synthesis of collagen, a protein that has many connective functions in the body (Arrigoni et al., 2002).

Vitamin $\mathrm{B}_{6}$ (Pyridoxine) is one of the water soluble vitamins that can influences cognitive performance, immune function, and steroid hormone activity (Ellie \& Sharon, 2008). The pyridoxine level ranged from 372 to $789 \mathrm{mg} / \mathrm{kg}$, for NERICA-5 and NERICA-9, respectively. This range was significantly $(\mathrm{p} \leq 0.05)$ higher than 1.5 to $16.8 \mathrm{mg} / \mathrm{kg}$ reported 


\section{Macrothink

for Siam rice and Fragrant rice (Mohd et al., 2007).

Thiamine (vitamin $\mathrm{B}_{1}$ ) varied between 116 and $383 \mathrm{mg} / \mathrm{kg}$ for NERICA-7 and NERICA-9, respectively. The vitamin was not detected in Aroso. Some studies indicated that thiamine content of $0.463 \mathrm{mg} / \mathrm{kg}$ was recorded for artisanal rice, $1.134 \mathrm{mg} / \mathrm{kg}$ for tilde rice and 0.52 mg / kg for 'Njavara' rice (Umar et al., 2013; Manful \& Swetman, 2007). The high thiamine content in NERICA implied that its consumption help prevent deficiency diseases associated with inadequate intake of thiamine

The content of folate ranged from 66.6 to $142 \mathrm{mg} / \mathrm{kg}$ for NERICA-7 and NERICA-6, respectively. Folates play a key role in DNA biosynthesis and in the methylation cycle ((Holazova et al., 2007).

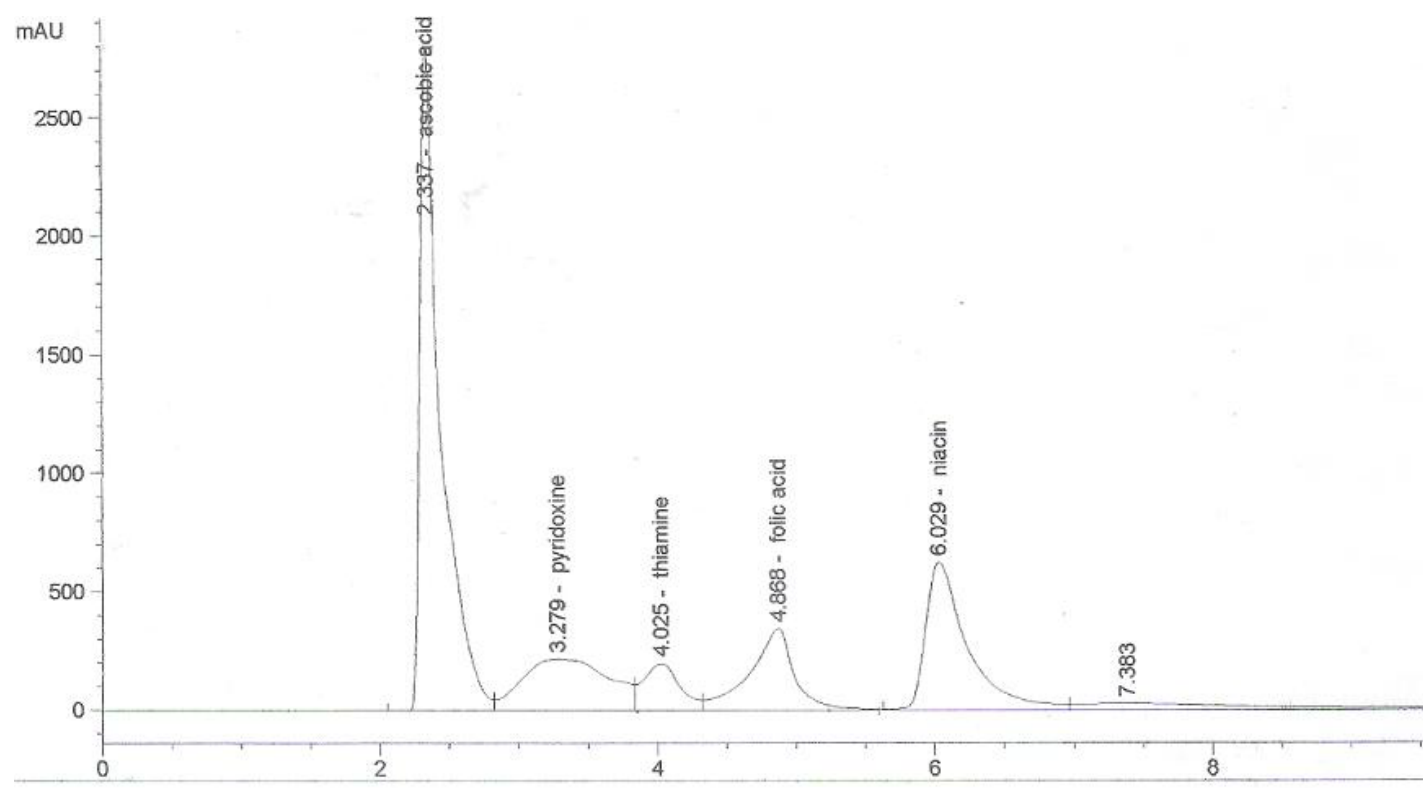

Figure 1. Chromatogram of vitamin standard

Table 2. Water soluble vitamin content of NERICA rice varieties ( $\mathrm{mg} / \mathrm{kg}$ dry weight basis)

\begin{tabular}{llllllll}
\hline Parameters & NERICA 2 & NERICA 5 & NERICA 6 & NERICA 7 & NERICA 8 & NERICA 9 Aroso \\
\hline Ascorbic acid & $36.2 \pm 1.0^{\mathrm{a}}$ & $20.8 \pm 0.5^{\mathrm{b}}$ & $19.2 \pm 1.0^{\mathrm{b}}$ & $8.1 \pm 0.9^{\mathrm{c}}$ & $10.9 \pm 0.8^{\mathrm{c}}$ & $9.5 \pm 0.5^{\mathrm{c}}$ & $9.4 \pm 0.04^{\mathrm{c}}$ \\
Pyridoxine & $449 \pm 14^{\mathrm{c}}$ & $372 \pm 2.4^{\mathrm{d}}$ & $760 \pm 2.0^{\mathrm{a}}$ & $373 \pm 10^{\mathrm{d}}$ & $632 \pm 13^{\mathrm{b}}$ & $789 \pm 12^{\mathrm{a}}$ & $750 \pm 2.0^{\mathrm{a}}$ \\
Thiamine & $264 \pm 8.0^{\mathrm{c}}$ & $212 \pm 2.0^{\mathrm{d}}$ & $300 \pm 3.4^{\mathrm{b}}$ & $116 \pm 9.0^{\mathrm{f}}$ & $150 \pm 2.4^{\mathrm{e}}$ & $383 \pm 3.8^{\mathrm{a}}$ & ND \\
Folate & $127 \pm 2.2^{\mathrm{b}}$ & $80 \pm 4.8^{\mathrm{d}}$ & $142 \pm 6.0^{\mathrm{a}}$ & $66.6 \pm 2.8^{\mathrm{e}}$ & $102 \pm 3.3^{\mathrm{c}}$ & $138 \pm 4.3^{\mathrm{a}}$ & $80 \pm 0.9^{\mathrm{d}}$ \\
\hline
\end{tabular}

*Aroso reference rice.

Mean \pm SD - Mean and standard deviation of replicate analysis.

Values with different superscript in the same row are significantly different $(\mathrm{p} \leq 0.001)$. 


\section{MInstitute ${ }^{\text {Macrothink }}$}

\subsection{Carbohydrate}

The total and reducing sugars are presented in Table 3. These parameters varied between 96 and $157 \mathrm{mg} / \mathrm{g}$ for total sugar and between 60 and $117 \mathrm{mg} / \mathrm{kg}$ for reducing sugar. The range of 140 to $360 \mathrm{mg}$ / g total sugar was reported for Basmati rice (Davinda \& Longvah, 2011). It has been observed that sugar has no special nutritional value other than improving the taste and increasing calorie intake. High caloric food is believed to increase the risk of coronary disease and obesity (Stubbs et al., 2000). Consumption of high sugar and starchy food may compromise attainment of adequate dietary and mineral intake from whole food sources (Thomas et al., 2013).

The amylose proportion of the starch reported in this work compares with 21.7 to $26 \%$ reported for some cultivars of NERICA (Africa Rice Center (WARDA), 2008). Rice are grouped based on their amylose content into waxy (2\%), very low (3-9\%), intermediate $(20-25 \%)$ and high (> 25\%) (Juliano,1985). From our result, apart from NERICA-6 and NERICA-8 which recorded amylose values greater than $27 \%$, NERICA rice varieties could be categorized as intermediate. Amylose content of grains has been observed to differ due to factors such as genotype, environmental conditions, and agricultural practice, climatic conditions and soil type on which the rice is grown (Thomas et al., 2013; Eggum et al., 1982).

High amylose starches are a source of resistant starch and have been associated with reduced susceptibility to enzymatic hydrolysis of cooked rice starches whereas starches with low amylose content digests easily (Riley et al., 2014; Zhou et al., 1998). It has been reported that structures or conformation of starch have great influence on starch digestibility (Zhou et al., 1998).

Table 3. Total sugar, reducing sugar, starch and amylose content of NERICA rice

\begin{tabular}{llllllll}
\hline Samples & NERICA 2 & NERICA 5 & NERICA 6 & NERICA 7 & NERICA 8 & NERICA 9 & Aroso \\
\hline Reducing sugar (mg/g) & $117 \pm 1.3^{\mathrm{a}}$ & $91 \pm 4.3^{\mathrm{b}}$ & $92 \pm 4.5^{\mathrm{b}}$ & $60 \pm 1.6^{\mathrm{e}}$ & $84 \pm 2.5^{\mathrm{c}}$ & $71 \pm 4.7^{\mathrm{d}}$ & $80 \pm 1.4^{\mathrm{c}}$ \\
Total sugar (mg/g) & $109 \pm 2.8^{\mathrm{c}}$ & $113 \pm 0.5^{\mathrm{b}}$ & $157 \pm 6.3^{\mathrm{a}}$ & $148 \pm 1.0^{\mathrm{ab}}$ & $141 \pm 3.8^{\mathrm{b}}$ & $96 \pm 3.8^{\mathrm{d}}$ & $144 \pm 1.2^{\mathrm{b}}$ \\
Starch (mg/g) & $183 \pm 0.1^{\mathrm{a}}$ & $182 \pm 0.2^{\mathrm{a}}$ & $175 \pm 2.3^{\mathrm{b}}$ & $171 \pm 0.5^{\mathrm{b}}$ & $178 \pm 3.1^{\mathrm{b}}$ & $182 \pm 0.9^{\mathrm{a}}$ & $188 \pm 2.0^{\mathrm{a}}$ \\
Amylose (\%) & $21 \pm 2.6^{\mathrm{b}}$ & $19 \pm 1.0^{\mathrm{b}}$ & $30 \pm 3.2^{\mathrm{a}}$ & $19 \pm 1.0^{\mathrm{b}}$ & $27 \pm 3.0^{\mathrm{a}}$ & $24 \pm 3.0^{\mathrm{b}}$ & $26 \pm 0.8^{\mathrm{ab}}$ \\
Amylopectin (\%) & $79 \pm 2.0^{\mathrm{a}}$ & $81 \pm 1.0^{\mathrm{a}}$ & $70 \pm 2.2^{\mathrm{c}}$ & $81 \pm 0.5^{\mathrm{a}}$ & $73 \pm 2.8^{\mathrm{c}}$ & $76 \pm 2.0^{\mathrm{b}}$ & $74 \pm 0.6^{\mathrm{c}}$ \\
Amylose: & $1: 3.76$ & $1: 4.26$ & $1: 2.38$ & $1: 4.40$ & $1: 2.7$ & $1: 3.16$ & $1: 2.8$ \\
Amylopectin ratio & & & & & & & \\
\hline
\end{tabular}

*Aroso reference rice.

Mean \pm SD mean and standard deviation of replicate analysis.

Values with different superscript in the same row are significantly different $(\mathrm{P} \leq 0.05)$.

\subsection{In-vitro Starch Digestibility}

The in-vitro starch hydrolysis is presented in Figure 1. The starch hydrolysis curves were analyzed using first order kinetic equation and the parameters for the digestibility of rice starch are presented in Table 5. The equilibrium concentration $(\mathrm{C} \infty)$ ranged from 45.3 to 


\section{Macrothink}

$55.7 \%$, Aroso recorded the highest value whereas NERICA-2 recorded the least value. The glycemic index for NERICA rice varied between 81.9 and $92.1 \%$ for NERICA 2 and NERICA 5, respectively. The value reported in this study compared favourably with the range of $64-93 \%$ and $68-109.2 \%$ reported in freshly cooked white and brown rice, respectively (Jenkins et al., 1981). According to Jenkins et al. (1981), foods with GI of $\leq 55$ are classified as low GI foods, from 56-69, moderate and $\geq 70$ are classified as high GI foods therefore, NERICA rice could also be said to have a high glycemic load.



Figure 2. In-vitro starch hydrolysis rate of NERICA rice as compared to Aroso (control)

Table 4. Equilibrium concentration $\left(\mathrm{C}_{\infty}\right)$, Rate constant $(\mathrm{k})$, Area under curve (AUC) hydrolysis Index, Glycemic Index of NERICA rice

\begin{tabular}{llllll}
\hline Sample & $\mathrm{C}_{\infty}$ & $\mathrm{k}$ & AUC & HI $(\%)$ & GI $(\%)$ \\
\hline NERICA 2 & $45.3 \pm 0.9^{\mathrm{e}}$ & $0.03 \pm 0.001^{\mathrm{a}}$ & $6606 \pm 10^{\mathrm{g}}$ & $76.8 \pm 1.5^{\mathrm{g}}$ & $81.87 \pm 0.9^{\mathrm{e}}$ \\
NERICA 5 & $53.1 \pm 0.2^{\mathrm{b}}$ & $0.035 \pm 0.003^{\mathrm{a}}$ & $8028 \pm 2.0^{\mathrm{b}}$ & $95.4 \pm 0.9^{\mathrm{b}}$ & $92.08 \pm 1.2^{\mathrm{b}}$ \\
NERICA 6 & $52.1 \pm 1.0^{\mathrm{c}}$ & $0.03 \pm 0.001^{\mathrm{a}}$ & $7392 \pm 1.8^{\mathrm{e}}$ & $85.9 \pm 0.2^{\mathrm{e}}$ & $86.86 \pm 0.9^{\mathrm{d}}$ \\
NERICA 7 & $51.8 \pm 0.6^{\mathrm{cd}}$ & $0.03 \pm 0.0002^{\mathrm{a}}$ & $7605 \pm 6.0^{\mathrm{d}}$ & $88.4 \pm 0.4^{\mathrm{d}}$ & $88.24 \pm 0.5^{\mathrm{c}}$ \\
NERICA 8 & $50.5 \pm 0.1^{\mathrm{d}}$ & $0.03 \pm 0.005^{\mathrm{a}}$ & $7298 \pm 0.9^{\mathrm{f}}$ & $84.8 \pm 0.5^{\mathrm{f}}$ & $86.26 \pm 0.3^{\mathrm{d}}$ \\
NERICA 9 & $52.5 \pm 0.1^{\mathrm{c}}$ & $0.03 \pm 0.0008^{\mathrm{a}}$ & $7707 \pm 12^{\mathrm{c}}$ & $89.6 \pm 2.0^{\mathrm{c}}$ & $88.92 \pm 0.7^{\mathrm{c}}$ \\
AROSO* $^{\mathrm{a}}$ & $58.6 \pm 0.3^{\mathrm{a}}$ & $0.03 \pm 0.0001^{\mathrm{a}}$ & $8603 \pm 3.0^{\mathrm{a}}$ & $100 \pm 00^{\mathrm{a}}$ & $\pm 0.1^{\mathrm{a}}$ \\
\hline
\end{tabular}

*Aroso reference rice.Mean $\pm \mathrm{SD}$ - Mean and standard deviation of replicate analysis.

Values with different superscript in the same column are significantly different $(\mathrm{P} \leq 0.001)$. 
Equilibrium Concentration $(\mathrm{C} \alpha)$, Kinetic constant $(k)$, hydrolysis index (HI) glycemic index (GI).

Area under curve (AUC).

Correlation coefficients (Table 6), indicated negative correlation between fiber content and glycemic index $(r=-0.814, p \leq 0.01)$, fiber and hydrolysis index $(r=-0.731, p \leq 0.01)$, by implication, it showed that the higher the fiber the less the hydrolysis index and also the glycemic load.

Table 5. Pearson correlation coefficient (r) between some parameters of starch hydrolysis

\begin{tabular}{llllll}
\hline & G I & H I & Amylose & Amylopectin & Starch \\
\hline Hydrolysis Index & $0.962^{* *}$ & & & & \\
Amylose & 0.052 & -0.012 & & & \\
Amylopectin & -0.052 & 0.012 & $-0.998^{* *}$ & & \\
Starch & 0.349 & 0.369 & 0.086 & -0.086 & \\
Fiber & -0.814 & -0.731 & -0.328 & 0.328 & 0.012 \\
\hline
\end{tabular}

**. Correlation is significant at the 0.01 level (1-tailed).

\section{Conclusion}

The findings of this study revealed that NERICA rice contains essential nutrients could compare in quality with other rice varieties. However, it has a high glycemic index which could be a grave concern especially in Africa where diabetes and other non communicable diseases are becoming endemic.

\section{Conflict of Interest}

There is no conflict of interest.

\section{Acknowledgement}

The author wish to express our gratitude to the management of Africa rice Centre, International Institute of Tropical Agriculture, Ibadan, Nigeria for making samples available for this study. The study is self financed, no grant or aids was received from any organization.

\section{References}

A.O.A.C. (2000). Official Methods of Analysis, Association of Official Analytical Chemists (AOAC). Washington DC.

Africa Rice Center. (2008). (WARDA)/FAO/SAA, NERICA: the New Rice for Africa - a Compendium. In E. A. Somado, R. G. Guei, \& S. O. Keya (Eds.), Cotonou, Benin; Africa Rice Centre (WARDA) Rome, Italy; FAO, Tokyo, Japan. Sasakawa Africa Association.

Al-kanhai, M. A., Al-Mohizeq, I. S., Othaimeen, A. L., \& Khan, M. A. (1999). Nutritive value of various rice based dishes in Saudi Arabia Ecology of Food and Nutrition, 38, 223-235.

Anuonye J. C., Chinma, C. E., Olukayode, J., \& Suleiman, A. (2016). Nutrient composition, 
amylose content and pasting characteristics of some elite accessions of NERICA ricen Journal of Food Technology Research, 3(1), 36-47.

AOAC. (1984). Official methods of analysis (13th ed.). Arlington, VA, USA: Association of Official Analytical Chemists.

Arrigoni, O., \& De Tulio, M. C. (2002). Ascorbic acid: much more than just an antioxidant. Biochim. Biophys. Acta, 1569, 1-9. https://doi.org/10.1016/S0304-4165(01)00235-5

Auderbert, A., Dingkuhn M., Monty, J. P., \& David, E. J. (1998). Physiological Mechanism for Vegetative Vigor of Interspecific upland rice-implications for weed competitiveness Japanese Journal of Cop Sciences, 67(2), 358-59.

Ayamdoo, A. J., Amikizunu, J., \& Abdul-Razak, A. (2015). Effects of varied parboiling conditions on proximate and mineral composition of Jasmine-85 and NERICA-14 rice varieties in Ghana International Journal of Food Research, 1-11.

Bainbridge, Z., Tomlins, K., Wellings, K., \& Westby, A. (1996). Method of assessing Quality Charactristics of non grain starch staples Part 3, Laboratory Methods, Natural Resources Institute Chatham, UK.

Berechet G., \& Segal, R. (2007). Vitamins Retention in some Microwave Dishes. The Annals of the University Dunarea de-Jos of Galati Fascicle IV-Food Technology, 27-32.

Cadoni, P., \& Angelucci, F. (2013). Analysis of Incentives and disincentives for Rice in Nigeria Technical note series MAFAP, FAO, Rome

Davinda, S., \& Longvah, T. (2011). Analysis of digestible carbohydrates in different varieties of Basmati rice and other popular cereal samples using HPLC-RI World Journal of Diary and Food Sciences, 6(2), 146-151.

Deepa, G., Singh, V., \& Maidu, K. A. (2010). Comparative study on starch digestibility glycemic index and resistance starch of pigmented ('Njavara' and 'Jyothi') and a non pigment ('IR 64') rice varieties. Journal of Food Science and Technology, 47(6), 644-649. https://doi.org/10.1007/s13197-010-0106-1

DingKuhn, M., Monty, P. J., \& Johnson, D. E. (1998). Growth and Yield Potential of Oryza Sativa and O. Glaberrima Upland Rice Cultivars and Their Interspecific Pogenies. Field Crops Research, 57(1), 57- 59. https://doi.org/10.1016/S0378-4290(97)00115-9

Eggum, B. O., Juliano, B. O., \& Maningat, C. C. (1982). Protein and energy utilization of rice milling fractions by rats. Plant Food Human Nutrition, 31, 371-376. https://doi.org/10.1007/BF01094048

Ellie, W., \& Sharon, R. R. (2008). The Water Soluble Vitamins: B Vitamins and Vitamin C. In Understanding Nutrition (11th Edition) Thomson Wadsworth. FAO 2000. FAO rice information (Vol. 2). Rome, Italy: Food and Agriculture Organization of the United Nations.

Falade, O. S., Owoyomi, O., Harwood, C. E., \& Adewusi, S. R. A. (2005). chemical composition and starch hydrolysis of acacia colei and acacia tumida seeds. Cereal Chemistry, 82(5), 479-484. https://doi.org/10.1094/CC-82-0479

Falade K. O., Semon, M., Fadairo, O. S., Oladunjoye, A. O., \& Orou, K. K. (2014). Functional and physico-chemical properties of flours and starches of African rice cultivars Food Hydrocolloids, 39, 41-50. https://doi.org/10.1016/j.foodhyd.2013.11.002 


\section{Macrothink}

Futakuchi, K., \& Si, M., (2009). Better exploitation of African Rice (Oryza glaberrima Steud.) in varietal development for resource-poor farmers in West and Central Africa. Agric, 4, 96-102.

Goni, I., Garcia-Alonso, A., \& Saura-Calixto, F. (1997). A starch Hydrolysis Procedure to Estimate Glycemic Index Nutrition Research, 17(3), 427-437.

Grandfeidt, H. N., Veenstra, J., \& Hudson, G. J. (1992). Measurement of rapidly available glucose (RAG) in plant foods: a potential in in-vitro predictor of the glycemic responses British. Journal of Nutrition, 46, 649-660.

James, C. S. (1996). Analytical Chemistry of Foods Mackie Academic and Professionals Ltd Glasgow, 135.

Jeevetha, S., Barakatun-Nisak, M. Y., Ngan H., Ismail, A., \& Azlan, A. (2014). Relationship between Amylose Content and Glycemic Index of Commonly Consumed White Rice Journal of Agriculture and Veterinary Science, 7(9), 12-18.

Jenkins, D. J. A., Wolever, T. M. S., Taylor, R. H., Fleiden, H., Baldwin, J. M., Bowling, A., Newman, H. C., Jenkins, A., \& Golf, D. V. (1981). Glycemic Index of foods: a physiological basis for carbohydrate exchange American Journal of Clinical Nutrition, 34, 362-366. https://doi.org/10.1093/ajen/34.3.362

Jones, M. P. M., Dingkuhn, D., Johnson, E., \& Fagade, S. O. (1997). Interspecific hybridization: progress and prospect proceedings of the workshop: Africa/Asia Joint Research, Interspecific Hybridization between Africa and Asia Rice Species ed. \{Oryza glaberrima and Oryza sativa .Bouake: WARDA.

Juliano, B. O. (1985). Rice properties and processing Food Review International, 1(3), 432-445. https://doi.org/10.1080/87559128509540778

Khor, S., \& Tee, E. (1996). Development of a HPLC method for the simultaneous determination of several B-vitamins and Ascorbic Acid Malawian Journal Nutrition, 2, 49-65.

Manful, J. T., Swetman, A. A., Coker, R. D., \& Drunis, A. (2007). Changes in the thiamine and riboflavin contents of rice during artisanal parboiling in Ghana Tropical.Science, 47(4), 211-217

Mohd F. M. N., Norhayati, M. K., Zaiton, A., Norliza, A. H., \& Rusidah, S. (2015). Nutrient content in selected commercial rice in Malaysia: An update of Malaysian food composition database International Food Research Journal, 22(2), 768-776

Odenigbo, A. M., Ndindeng S. A., Nwankpa C. A., Woin N. and Ngadi M. (2013) In vitro Starch Digestibility and Nutritional Composition of Improved Rice Varieties from Cameroun European Journal of Nutrition \& Food Safety, 3(4), 134-145.

Oelke E. A. (1976). Amino acid content in wild rice (Zizania aquatic L.) grain. Agronomy Journal, 68, 146-148.

Oko, A. O. L., Ubi, B. E., Efisue, A. A., \& Dambaba, N. (2012). Comparative Analysis of the Chemical Nutrient Composition of Selected Local and Newly Introduced Rice Varieties grown in Ebonyi State of Nigeria. International Journal of Agriculture and Forestry, 2(2), 16-23. https://doi.org/10.5923/j.ijaf.20120202.04 


\section{MInstitute Macrothin}

Journal of Food Studies

ISSN 2166-1073

2018, Vol. 7, No. 1

Oko, A. O., \& Ugwu, S. I. (2011). The proximate and mineral compositions of five major rice varieties in Abakaliki South-Eastern Nigeria International Journal of Plant Physiology and Biochemistry, 3(2), 25-27.

Olajire, A. A., \& Azeez, L. (2011).Total antioxidant activity, phenolic, flavonoid and ascorbic acid contents of Nigerian vegetables African Journal of Food Science and Technology, 2(2), 022- 029 .

Otemuyiwa, I. O., \& Adewusi, S. R. A. (2013). Simultaneous high performance liquid chromatography analysis of water soluble vitamins in some foods prepared by a Nigerian eatery African Journal of Food Science, 7(11), 415-420. https://doi.org/10.5897/AJFS2013.1086

Padovani, R. M., Lima, D. M., Colugnati, F. A. B., \& Rodriguez-Amaya, D. B. (2007). Comparison of proximate, mineral and vitamin composition of common Brazilian and US foods. Journal of Food Composition and Analysis, 20, 733-738. https://doi.org/10.1016/j.jfca.2007.03.006

Payne, W. J. A. (1990). An Introduction to Animal Husbandry in the Tropics Longman Publishers, Singapore, 92-110.

Riley, C. K., Bahado-Singh, P. S., Wheatley, A. O., \& Asemota, H. N. (2014). Physicochemical properties of low-amylose yam (Dioscorea spp.) starches and its impact on $\alpha$ - amylase degradation in vitro. International Journal of Nutrition and Food Sciences, 3(5), 448-454. https://doi.org/10.11648/j.ijnfs.20140305.23

Stubbs, J., Ferres, S., Horgan, G. (2000). Energy density of foods, effect on energy intake. Critical Reviews of Food Science and Nutrition, 40, 481-515. https://doi.org/10.1080/10408690091189248

Rohman, A., Helmiyati, S., Hapsari, M., \& Setyaningrum, D. L. (2014). Rice in health and nutrition. International Food Research Journal, 21(1), 13-24.

Thomas, R., Wan-Nadiah, W. A., \& Rajeev, B. (2013). Physiochemical properties, proximate composition, and cooking qualities of locally grown and imported rice varieties marketed in Penang, Malaysia. International Food Research Journal, 20(3), 1345-1351.

Umar, M. A., Ugonor, R., Akin-Osanaiye, C. B., \& Kolawole, S. A (2013). Evaluation Of Nutritional Value Of Wild Rice From Kaduna State, Central Nigeria. International Journal Of Scientific \& Technology Research, 2(7), 112-116.

Virmani, S. S. (2002). Progress and issues in development and use of hybrid rice in the tropics. In Proceedings of the 20th session of international rice commission, Bangkok, Thailand, p.128.

Wolever, T. M. S., \& Mchling, C. (2002). High-carbohydrate-low-glycemic index dietary advice improves glucose disposition index in subjects with impaired glucose tolerance. British Journal of Nutrition, 87, 477-487. https://doi.org/10.1079/BJN2002568

Zabidi, M. A., \& Abdul - Aziz, N. A. (2009). In vitro starch hydrolysis and estimated glycaemic index of bread substituted with different percentage of chempedak (Artocarpus integer) seed flour. Food Chemistry, 117, 64-68. https://doi.org/10.1016/j.foodchem.2009.03.077 


\section{Macrothink}

Journal of Food Studies

ISSN 2166-1073 2018, Vol. 7, No. 1

Zhou, M., Robards, K., Glennie-Holmes, M., \& Helliwell, S. (1998). Structure and pasting properties of oat starch. Cereal Chemistry, 75, 273-281. https://doi.org/10.1094/CCHEM.1998.75.3.273

Otemuyiwa, I. O. \& Adewusi, S. A. (2013). Simultaneous high performance liquid Chromatography analysis of water soluble Vitamins in some foods prepared by a Nigerian eatery. African Journal of Food Science, 7(11), 415-420. https://doi.org/10.5897/AJFS2013.1086

\section{Copyright Disclaimer}

Copyright for this article is retained by the author(s), with first publication rights granted to the journal.

This is an open-access article distributed under the terms and conditions of the Creative Commons Attribution license (http://creativecommons.org/licenses/by/3.0/). 